\title{
The influence of smoking and HIV infection on pulmonary function
}

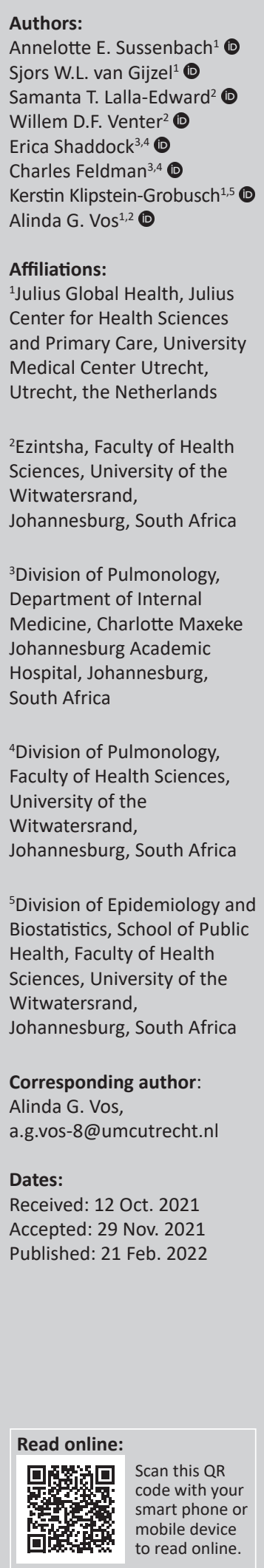

Background: Prevalence of HIV, smoking, and pulmonary infections in South Africa are high. Objectives: We investigated the role of smoking and HIV status on lung function.

Methods: This is a secondary analysis of a cross-sectional study conducted in South Africa. Data included demographics, pulmonary risk factors and a spirometry test to obtain the forced expiratory volume in one second (FEV1) and the ratio of FEV1/forced vital capacity (FVC). In the initial multivariable regression analysis, the effect of smoking on pulmonary function in HIV-positive adults was assessed. The analysis was repeated, assessing the influence of HIV status on lung function in both HIV-negative and HIV-positive smokers. The models were adjusted for age, sex, body mass index (BMI), time since HIV diagnosis, antiretroviral treatment (ART) use, occupational hazards, history of tuberculosis or pneumonia, indoor smoking and the presence of an indoor fireplace during childhood.

Results: This study included 524 people living with HIV (PLWH, 66.7\% female, mean age 40.9 years [s.d.; 9.4]) and 79 HIV-negative smokers (77.2\% male, mean age 34.4 years [s.d.: 12.1]). Of the PLWH, 118 (22.5\%) were past or current smokers and 406 (77.5\%) were non-smokers. Smoking was not associated with changes in the FEV1 or FEV1/FVC ratio in multivariable regression analysis. In the second analysis, HIV status was also not associated with reduced pulmonary function following adjustment for confounders.

Conclusion: Neither smoking nor being HIV-positive was associated with decreased pulmonary function in this relatively young population. These findings should be confirmed in a longitudinal study, including an older population.

Keywords: HIV; lung function; PLWH; South Africa; spirometry; sub-Saharan Africa.

\section{Introduction}

HIV has infected over 75 million people, with over 32 million deaths reported worldwide since its emergence in the 1980s. ${ }^{1}$ Even though there is no cure for HIV infection, the use of antiretroviral treatment (ART) has resulted in a near normal life expectancy for people living with HIV $(\mathrm{PLWH}){ }^{2,3}$

This increased life expectancy has resulted in an increase in age-related comorbid diseases, such as cardiovascular diseases, diabetes mellitus and cancers. ${ }^{2,3}$ Untreated HIV is associated with an increased vulnerability to pulmonary infections, such as pneumonia and pulmonary tuberculosis (TB), resulting from the immune dysfunction caused by the virus. ${ }^{2,45,6}$ Although ART restores immune function in $\mathrm{PLWH}$, immunity does not return to normal levels and chronic immune activation persists. This low-grade immune activation is also manifested in the immune cells that reside in the lungs and may be responsible for HIV-related lung damage. ${ }^{7}$ Furthermore, ART and HIV might be independently associated with a decline in pulmonary function. ${ }^{8,9}$

Although smoking rates are decreasing globally, about $80 \%$ of smokers live in low- and middleincome countries (LMICs), which also have the highest prevalence of HIV.1,10,11 In high-income countries, the incidence of smoking amongst PLWH is still two to three times higher than in people without HIV.12 The prevalence of smoking amongst PLWH in sub-Saharan Africa ranges from lower to higher than the HIV-uninfected community. $13,14,15,16,17,18,19,20,21$ In South Africa, the prevalence of smoking in PLWH is estimated to be around 20\%. ${ }^{13,16}$ Although rates differ between provinces and different social groups, these numbers are concerning, given the background of

How to cite this article: Sussenbach AE, Van Gijzel SWL, Lalla-Edward ST, et al. The influence of smoking and HIV infection on pulmonary function. S Afr J HIV Med. 2022;23(1), a1329. https://doi.org/10.4102/sajhivmed.v23i1.1329

Copyright: ㄷ 2022. The Authors. Licensee: AOSIS. This work is licensed under the Creative Commons Attribution License. 
pre-existing lung damage because of (opportunistic) infections and the possible negative effects of HIV and ART on lung function.

Many studies have investigated the added negative effect of smoking on pulmonary function in PLWH. ${ }^{4,8,22,23,24,25}$ The majority of these cross-sectional studies reported that the negative impact of smoking on lung function in PLWH could not be attributed to a history of pulmonary infections, such as $\mathrm{TB}$ and pneumonia alone. Therefore, this study aimed to investigate the influence of smoking and HIV infection on pulmonary function in Johannesburg, South Africa.

\section{Methods}

Data from two existing study databases were combined in this analysis.

\section{Study population and data collection}

Study Group I: The aim of Study I was to investigate the interaction between HIV, ART, pulmonary function, and cardiovascular traits in an urban South African population. The inclusion criteria for this study were as follows: (1) confirmed HIV-positive status, age $\geq 18$ years and enrolled at the HIV clinic at the Charlotte Maxeke Johannesburg Academic Hospital (CMJAH); (2) individuals aged $\geq 18$ years with unknown HIV status who participated in the Universal Test and Treat (UTT) programme at CMJAH and who agreed to share their test result with the researcher. The South African UTT initiative was founded in 2016 and aimed to test as many people as possible, and to initiate ART regardless of the CD4 count in those testing positive for HIV. ${ }^{26,27}$

Participants who are HIV negative were enrolled through the UTT programme. Participants unable to undergo study procedures for any reason or unwilling to share HIV test results or with unknown HIV status were excluded from the study. A written informed consent was obtained from all study participants.

Study Group II: This study aimed to investigate the interaction between HIV, ART and cardiopulmonary function in an urban South African population. Study II was also conducted at CMJAH and included PLWH not yet on ART, wellcharacterised PLWH on first- and second-line ART, as well as HIV-negative controls as previously described..$^{28}$ Participants were recruited from randomised controlled trials (RCTs) comparing ART regimens. Inclusion and exclusion criteria included those of Study I, and additionally excluded pregnant women, people with impaired kidney function and people on active TB treatment. The methods are described in more detail in previous publications. ${ }^{15,29}$

In both studies, a spirometry test was performed, next to questionnaires on participants' demographics, characteristics and respiratory profile. The respiratory questionnaire included The St George's Respiratory Questionnaire (SGRQ). ${ }^{30}$ Spirometry was performed with a handheld device, and included pre- and post-bronchodilator measurements. Acceptability and reproducibly were based on guidelines of the American Thoracic Society and European Respiratory Society. ${ }^{31,32}$ More details on measurements can be found in the supplementary file (Table 1-A1).

A written informed consent was obtained from all study participants. REDCap version 9.7.8 was used for data collection in both studies. ${ }^{39,40}$

\section{Data analysis}

Baseline characteristics of participants were presented as mean with standard deviation (s.d.) or as frequencies and percentages, unless stated otherwise. The characteristics were compared using a $t$-test for continuous variables and the Chi-square test for categorical variables.

The primary outcome of this study was post-bronchodilator FEV1. The secondary outcome was the post-bronchodilator FEV1/forced vital capacity (FVC) ratio.

Multivariable regression analyses were performed to test the relationship between smoking and pulmonary function in PLWH. The following variables were regarded as confounders based on the literature and were included in the models using forced entry of variables: age, sex, body mass index (BMI), time since HIV diagnosis, ART duration, history of pneumonia, occupational hazard, indoor smoking in the household and presence of a fireplace during childhood. ${ }^{9,23,41}$ The first model assessed the effect of smoking on postbronchodilator FEV1, whilst the second model was corrected for the above-mentioned covariates. In a third model, a history of TB was added to account for possible effect modification. All steps were repeated using the FEV1/FVC ratio as outcome.

In an additional analysis, smoking was treated as a continuous variable using pack-years, with zero pack-years for non-smokers (information on pack-years was only available for Study II).

In a second analysis, the influence of HIV on lung function in smokers was assessed using the same steps as described above. HIV status was the main determinant, and the same confounders were taken into account, including smoking status, except for the HIV-related variables, including time since HIV diagnosis and ART duration.

Multicollinearity was checked for all variables in the models. ${ }^{42}$ A two-sided $P$-value of $<0.05$ was considered to be statistically significant. Initially, complete case analysis was performed. Subsequently, missing data were imputed using multiple imputation with the R-package MICE. ${ }^{43,44} \mathrm{R}$ version 4.0.0 and Statistical Package for the Social Sciences (SPSS) version 26 were used for data analysis. ${ }^{45,46}$

\section{Ethical considerations}

All participants were required to sign a written informed consent form prior to enrolment. In case the participant was 
not able to read the English form, an additional consent form had to be signed that verbal explanation of the form was sufficient. The University of the Witwatersrand, Human Research Ethics Committee (HREC) approved Study I (M190628) and Study II (M160130).

\section{Results}

In total, 524 PLWH were included (66.7\% female), of whom 118 individuals were past or current smokers (118/524 $(22.5 \%)$ (Figure 1). Four were excluded from analyses because of missing information on the smoking status. The

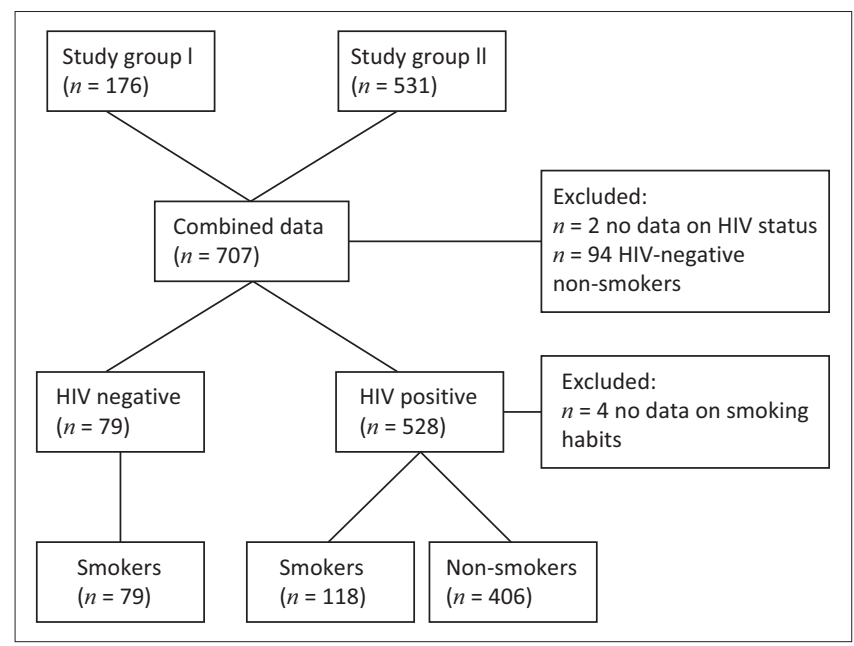

FIGURE 1: Flow diagram of study composition. mean age was 40.9 years (s.d.: 9.5), the mean time from HIV diagnosis was 92.3 months (s.d.: 69.6) and the mean ART duration was 74.5 months (s.d.: 60.6). One-third of the participants had been previously diagnosed with $\mathrm{TB}$ $(33.0 \%)$, and approximately $10 \%$ had been previously diagnosed with pneumonia.

Past or current smokers were more likely to be men; had a lower BMI; were less likely to be on ART; were more likely to consume alcohol; and were more likely to be exposed to chemicals, gases or fumes; working in a dusty job; or working in the farming or mining industry for more than a year (Table 1).

Smoking was not significantly related to post-bronchodilator FEV1 or the FEV1/FVC ratio following regression analysis (Table 2). There was no relationship between FEV1 and time since HIV diagnosis or time on ART. Adding TB to the models did not alter the relationship between smoking and FEV1 or the FEV1/FVC ratio. Tuberculosis was associated with a significant decline in both the FEV1 and the FEV1/ FVC ratio.

Similar results were reported when smoking was quantified using pack-years (only available for Study II), that is, smoking not being significantly associated with FEV1 nor FEV1/FVC (data not shown). However, the Spearman correlation coefficient between pack-years and pulmonary function was $R=0.40(P<0.01)$.

TABLE 1: Baseline characteristics of the study population stratified by smoking.

\begin{tabular}{|c|c|c|c|c|c|c|c|c|c|c|c|c|}
\hline \multirow[t]{3}{*}{ Characteristics } & \multicolumn{8}{|c|}{ HIV-positive } & \multirow{2}{*}{\multicolumn{4}{|c|}{$\begin{array}{c}\text { HIV-negative: } \\
\text { Past or current smokers }\end{array}$}} \\
\hline & \multicolumn{4}{|c|}{ Non-smokers } & \multicolumn{4}{|c|}{ Past or current smokers } & & & & \\
\hline & $n$ & $\%$ & Mean & s.d. & $n$ & $\%$ & Mean & s.d. & $n$ & $\%$ & Mean & s.d. \\
\hline & 406 & - & - & - & 118 & - & - & - & 79 & - & - & - \\
\hline Age (years)* & - & - & 40.65 & 8.84 & - & - & 41.83 & 11.39 & - & - & 34.43 & 12.08 \\
\hline Non-black & 1 & 0.2 & - & - & 3 & 2.5 & - & - & 8 & 10.1 & - & - \\
\hline Male & 98 & 24.1 & - & - & 77 & 65.3 & - & - & 61 & 77.2 & - & - \\
\hline Time since the HIV diagnosis (months)* & 93.25 & 67.75 & - & - & 87.55 & 74.13 & - & - & - & - & - & - \\
\hline HIV positive on ART & 339 & 83.5 & - & - & 85 & 72.0 & - & - & - & - & - & - \\
\hline ART duration (months)* & - & - & 76.85 & 58.54 & - & - & 69.02 & 66.64 & - & - & - & - \\
\hline Body mass index $\left(\mathrm{kg} / \mathrm{m}^{2}\right)^{*}$ & - & - & 27.72 & 6.61 & - & - & 25.65 & 5.91 & - & - & 23.70 & 5.09 \\
\hline Education: secondary completed or higher & 350 & 87.1 & - & - & 94 & 80.3 & - & - & 73 & 93.6 & - & - \\
\hline \multicolumn{13}{|l|}{ Work status } \\
\hline Employed & 138 & 34.2 & - & - & 47 & 40.2 & - & - & 53 & 67.9 & - & - \\
\hline Unemployed & 258 & 63.9 & - & - & 65 & 55.6 & - & - & 17 & 21.8 & - & - \\
\hline Retired & 6 & 1.5 & - & - & 3 & 2.6 & - & - & 1 & 1.3 & - & - \\
\hline Student & 2 & 0.5 & - & - & 2 & 1.7 & - & - & 7 & 9.0 & - & - \\
\hline In stable relationship $\dagger$ & 143 & 35.4 & - & - & 40 & 34.2 & - & - & 15 & 19.0 & - & - \\
\hline Alcohol use $\dagger$ & 184 & 45.4 & - & - & 97 & 83.6 & - & - & 65 & 82.3 & - & - \\
\hline Fire time $[>$ daily $] \dagger$ & 267 & 65.9 & - & - & 68 & 57.6 & - & - & 61 & 77.2 & - & - \\
\hline Smoke household $\dagger$ & 75 & 18.7 & - & - & 31 & 27.0 & - & - & 18 & 22.8 & - & - \\
\hline Smoke household indoor $†$ & 51 & 12.7 & - & - & 17 & 14.8 & - & - & 11 & 14.5 & - & - \\
\hline Childhood fireplace $†$ & 268 & 66.0 & - & - & 87 & 74.4 & - & - & 57 & 73.1 & - & - \\
\hline Parental lung disease $\dagger$ & 23 & 5.7 & - & - & 7 & 5.9 & - & - & 2 & 2.5 & - & - \\
\hline Occupational hazard $\dagger$ & 40 & 9.9 & - & - & 27 & 22.9 & - & - & 5 & 6.3 & - & - \\
\hline History of tuberculosis & 132 & 32.6 & - & - & 40 & 33.9 & - & - & 2 & 2.5 & - & - \\
\hline History of pneumonia & 40 & 9.9 & - & - & 13 & 11.1 & - & - & 4 & 5.1 & - & - \\
\hline Asthma & 28 & 6.9 & - & - & 7 & 6.0 & - & - & 5 & 6.3 & - & - \\
\hline Breathing problems $\dagger$ & 16 & 4.0 & - & - & 10 & 8.5 & - & - & 6 & 7.7 & - & - \\
\hline
\end{tabular}

$\dagger$, Definitions of variables can be found in supplementary material (Table 1-A1). 
In the second analysis, 197 smokers were analysed (71.1\% part of Study II), of whom 118 were HIV-positive individuals (59.9\%) (Table 1). The mean age was 38.9 years (s.d.: 12.2), with $70.0 \%$ being male participants. The mean smoking time was 15.2 years (s.d.: 0.7). HIV status was not significantly associated with pulmonary function following regression analysis. Adding TB to the model did not alter results. A history of TB was significantly associated with a decline in both outcomes (Table 3).

TABLE 2: Results of multivariable analysis for post-bronchodilator (BD) forced expiratory volume in 1 second and forced expiratory volume in 1 second/forced vital capacity on HIV-positive participants.

\begin{tabular}{|c|c|c|c|c|}
\hline \multirow[t]{2}{*}{ Variable } & \multicolumn{2}{|c|}{$\begin{array}{l}\text { Model 1: without } \\
\text { history of TB }\end{array}$} & \multicolumn{2}{|c|}{$\begin{array}{l}\text { Model 2: with } \\
\text { history of TB }\end{array}$} \\
\hline & $\begin{array}{c}\text { Post-BD } \\
\text { FEV1 } \\
(\beta \text {-coefficient } \dagger)\end{array}$ & $\begin{array}{c}\text { Post-BD } \\
\text { FEV1/FVC } \\
\text { ( } \beta \text {-coefficient } \dagger)\end{array}$ & $\begin{array}{c}\text { Post-BD } \\
\text { FEV1 } \\
(\beta \text {-coefficient } \dagger)\end{array}$ & $\begin{array}{c}\text { Post-BD } \\
\text { FEV1/FVC } \\
\text { ( } \beta \text {-coefficient } \dagger \text { ) }\end{array}$ \\
\hline Smoking ever & -0.016 & 0.001 & -0.012 & 0.002 \\
\hline Age (years) & $-0.022 * *$ & $-0.002 * *$ & $-0.022 * *$ & $-0.002^{* *}$ \\
\hline Sex (male) & $0.838 * *$ & $-0.020 * *$ & $0.848 * *$ & $-0.002 * *$ \\
\hline BMI $\left(\mathrm{kg} / \mathrm{m}^{2}\right)$ & $-0.009 *$ & $-0.001^{*}$ & $-0.009 * *$ & $-0.001^{*}$ \\
\hline $\begin{array}{l}\text { Time since HIV } \\
\text { diagnosis (months) }\end{array}$ & $<0.001$ & $<0.001$ & $<0.001$ & $<0.001$ \\
\hline $\begin{array}{l}\text { ART duration } \\
\text { (months) }\end{array}$ & $<-0.001$ & $<-0.001$ & -0.001 & $<-0.001$ \\
\hline $\begin{array}{l}\text { Occupational } \\
\text { hazard } \ddagger\end{array}$ & 0.058 & $<0.001$ & 0.450 & $<-0.001$ \\
\hline $\begin{array}{l}\text { History of } \\
\text { pneumonia }\end{array}$ & $-0.142 *$ & $-0.022^{*}$ & -0.099 & -0.099 \\
\hline $\begin{array}{l}\text { Smoke household } \\
\text { indoor }\end{array}$ & -0.051 & 0.003 & -0.046 & 0.004 \\
\hline $\begin{array}{l}\text { Fireplace } \\
\text { childhood } \$\end{array}$ & $-0.121 * *$ & 0.001 & $-0.122^{*}$ & 0.001 \\
\hline History of TB & - & - & $-0.195 * *$ & $-0.017 * *$ \\
\hline
\end{tabular}

TB, tuberculosis; BD: bronchodilator; BMI, body mass index; FEV1, forced expiratory volume in 1 second; FVC, forced vital capacity; ART, antiretroviral treatment.

$*, P<0.05 ; * *, P<0.01$.

$\dagger, \beta$-Coefficients are the result of multivariable analysis and are unstandardised; $¥$, Definitions of variables can be found in Methods: Measurements.

TABLE 3: Results of multivariable analysis for post-bronchodilator (BD) forced expiratory volume in 1 second and forced expiratory volume in 1 second/forced vital capacity on smoking participants.

\begin{tabular}{|c|c|c|c|c|}
\hline \multirow[t]{2}{*}{ Variable } & \multicolumn{2}{|c|}{$\begin{array}{l}\text { Model 1: without } \\
\text { history of TB }\end{array}$} & \multicolumn{2}{|c|}{$\begin{array}{l}\text { Model 2: with } \\
\text { history of TB }\end{array}$} \\
\hline & $\begin{array}{c}\text { Post-BD } \\
\text { FEV1 } \\
\text { ( } \beta \text {-coefficient } \dagger)\end{array}$ & $\begin{array}{c}\text { Post-BD } \\
\text { FEV1/FVC } \\
\text { ( } \beta \text {-coefficient } \dagger \text { ) }\end{array}$ & $\begin{array}{c}\text { Post-BD } \\
\text { FEV1 } \\
(\beta \text {-coefficient } \dagger)\end{array}$ & $\begin{array}{c}\text { Post-BD } \\
\text { FEV1/FVC } \\
\text { ( } \beta \text {-coefficient } \dagger \text { ) }\end{array}$ \\
\hline HIV positive & -0.027 & -0.027 & 0.025 & 0.025 \\
\hline Age (years) & $-0.026 * *$ & $-0.026 * *$ & $-0.025 * *$ & $-0.025 * *$ \\
\hline Sex (male) & $0.771 * *$ & $0.771 * *$ & $0.768 * *$ & $0.768 * *$ \\
\hline BMI $\left(\mathrm{kg} / \mathrm{m}^{2}\right)$ & $-0.021 *$ & $-0.021 *$ & $-0.020 *$ & $-0.020 *$ \\
\hline $\begin{array}{l}\text { Time since the HIV } \\
\text { diagnosis (months) }\end{array}$ & $<0.001$ & $<0.001$ & 0.0001 & $<0.001$ \\
\hline $\begin{array}{l}\text { Occupational } \\
\text { hazard } \$\end{array}$ & 0.121 & 0.122 & 0.113 & 0.113 \\
\hline $\begin{array}{l}\text { History of } \\
\text { pneumonia }\end{array}$ & 0.115 & -0.115 & 0.195 & 0.195 \\
\hline $\begin{array}{l}\text { Smoke household } \\
\text { indoor }\end{array}$ & 0.034 & 0.034 & 0.033 & 0.033 \\
\hline $\begin{array}{l}\text { Fireplace } \\
\text { childhood } \ddagger\end{array}$ & $-0.260 *$ & $-0.260^{*}$ & $-0.274^{*}$ & $-0.274 *$ \\
\hline History of TB & - & - & $-0.224 *$ & $-0.224 *$ \\
\hline
\end{tabular}

$\mathrm{TB}$, tuberculosis; $\mathrm{BD}$, bronchodilator; $\mathrm{BMI}$, body mass index; FEV1, forced expiratory volume in 1 second; FVC, forced vital capacity.

$*, P<0.05 ; * *, P<0.01$

$\dagger, \beta$-Coefficients are the result of multivariable analysis and are unstandardised; $\$$, Definitions of variables can be found in Methods: Measurements.
Analyses based on data including multiple imputation for missing data showed comparable results (Supplementary Table 1-A1).

\section{Discussion}

In this study of PLWH carried out in Johannesburg, South Africa, no relationship between smoking or HIV positivity and FEV1 or the FEV1/FVC ratio was observed. However, a history of TB was associated with a decrease in lung function.

The finding of this study that smoking was not associated with a decrease in pulmonary function in PLWH was unexpected, yet interestingly in line with other crosssectional studies from high-income countries. ${ }^{4,23,47}$ In most studies, a decline in pulmonary function was explained by effects of HIV, or by irreversible pulmonary damage because of TB or pneumonia, and not by smoking. However, one study from Pittsburgh, United States, observed that smoking was significantly associated with diffusion impairment in PLWH. ${ }^{8}$ Cross-sectional studies from sub-Saharan Africa also found that smoking was not associated with decreased pulmonary function. ${ }^{9,24}$ In general, the average age of the study populations was around 50 years. We found that age was significantly associated with a decrease in lung function, suggesting that the deleterious effects of smoking on lung function may only become apparent with increasing age. Studies that did report any adverse effect of smoking on lung function often limited their inclusion to individuals over 40 years of age. ${ }^{23,24,25}$

The prevalence of ever smoking was found to be $22 \%$ in this study, in line with other studies from South Africa and other sub-Saharan African countries. ${ }^{12,48}$ However, studies have reported a higher prevalence of smoking in PLWH $34 \%-$ $37 \% \%^{13,15,19,49}$ ) than in the general population in South Africa, despite various cessation strategies implemented by the government. ${ }^{20,50,51}$ Other studies in sub-Saharan Africa reported a prevalence of smoking in HIV-positive men ranging from 9.7\% in Ethiopia to $54.8 \%$ in the Gambia. ${ }^{17,18,19,20,21}$ In the current study, there was no validation of self-reported smoking, whilst in most studies mentioned above, validation of current smoking was carried out by testing of urine samples for cotinine. Inadequate reporting of smoking could be a possible explanation for the lower prevalence of smoking in this study. Another explanation might be that in this study, there was a relatively lower prevalence reported from a single centre (CMJAH) in Johannesburg, Gauteng province, than in other provinces. ${ }^{52}$

Another explanation for the low prevalence of smoking might be in the selection of participants. Participants in Study Group I were recruited from the HIV clinic, and participants in Study Group II were recruited from RCTs. It may be the case that people participating in RCTs were more aware of health hazards or had a healthier lifestyle, associated with a lower smoking prevalence. A study, performed in 2011 in the same hospital as the current study, reported a smoking prevalence of $15 \%$ amongst PLWH, whilst validation by urine samples showed a prevalence of almost $31 \%{ }^{20}$ 
Subsequent analysis of only smokers, including both HIVpositive and -negative participants, showed no effect of HIV on pulmonary function. Although no effect of HIV infection was observed, age was a significant factor in all models and analyses. This result supports our conclusion that the study population was too young to observe a possible additional negative effect of HIV on pulmonary function in smokers.

A limitation of this study is that CD4 cell count was not available. CD4 is a marker of immune impairment, and immune dysregulation may affect lung function. In this study, no association between ART and pulmonary function was observed, whilst some studies suggest that specific ARTregimens may be more strongly associated with decreased pulmonary function than other regimens. ${ }^{5,22,53,54}$ Another limitation is that this is a single-centre study, and, therefore, the results might not be generalisable to different contexts. As all but four participants were black, the study results are only applicable to black South Africans. Furthermore, no follow-up data are available. To investigate the true effect of smoking on pulmonary function, investigation of longitudinal data is necessary.

Finally, we only had information on pack-years available for current smokers; this is a powerful measure to reliably reflect the intensity of smoking, especially in LMICs, where the number of cigarettes smoked might be correlated with household income so pack-years could possibly be a more suitable and accurate measure than current versus past smoking. The correlation coefficient $R=0.40(P<0.01)$ between age and pack-years shows that participants with higher age also had significantly higher pack-years. This result supports our hypothesis that smoking may very well have influence on pulmonary function; however, our cohort is too young to establish this relationship.

Strengths of this study include the inclusion of a large urban population, representative of the general HIV-positive population in an urban environment in a low-middle income setting. Besides, we present a complementary analysis on the effect of HIV, smoking and lung function by analysing the effect of smoking in HIV-positive people, as well as in people who smoke the effect of HIV on lung function.

In summary, in a relatively young population of HIV-positive people, the negative impact of smoking on lung function is not yet measurable, and in smokers, HIV does not seem to be a risk factor for additional pulmonary impairment. A history of TB is, however, a strong risk factor for impaired pulmonary function.

More research studies are needed to longitudinally investigate the influence of smoking on decreasing FEV1 and FEV1/FVC ratio in the aging HIV-positive population in sub-Saharan Africa. In the meantime, smoking should be discouraged on every occasion, given the high burden of $\mathrm{TB}$, associations with other lung infections and expected persistent lung damage in this population.

\section{Acknowledgements}

The authors thank all participants for their cooperation in this study.

\section{Competing interests}

The authors declare that they have no financial or personal relationships that may have inappropriately influenced them in writing this article.

\section{Authors' contributions}

A.E.S., A.G.V. and K.K.G. contributed to the conception or design of the work. A.G.V., K.K.G., S.T. L-E., W.D.F.V., E.S and C.F conceived the original studies. A.E.S. and S.W.L.v.G. contributed to data collection. A.E.S. built the models and carried out the data analysis and interpretation. A.G.V. and K.K.G. supervised the project. A.E.S. and A.G.V. wrote the manuscript with input from all authors.

\section{Funding information}

The authors received no financial support for the research, authorship and/or publication of this article. The research study reported in this publication was supported by the National Heart, Lung, and Blood Institute of the National Institutes of Health and the Fogarty International Center under Award No. UG3HL156388. The content is solely the responsibility of the authors and does not necessarily represent the official views of the National Institutes of Health and the Fogarty International Center.

\section{Data availability}

The de-identified data sets used and/or analysed during the current study are available from the corresponding author upon reasonable request.

\section{Disclaimer}

The views and opinions expressed in this article are those of the authors and do not necessarily reflect the official policy or position of any affiliated agency of the authors.

\section{References}

1. Global Health Observatory - HIV. WHO.int [homepage on the Internet]. [cited 2020 Feb 02]. Available from: https://www.who.int/gho/hiv/en/

2. Guaraldi G, Orlando G, Zona S, et al. Premature age-related comorbidities among HIV-infected persons compared with the general population. Clin Infect Dis Off Pub Infect Dis Soc Am. 2011;53(11):1120-1126. https://doi.org/10.1093/cid/cir627

3. Staitieh B, Guidot DM. Noninfectious pulmonary complications of human immunodeficiency virus infection. Am J Med Sci. 2014;348(6):502-511. https:// doi.org/10.1097/MAJ.0000000000000318

4. Cui Q, Carruthers S, Mclvor A, Smaill F, Thabane L, Smieja M. Effect of smoking on lung function, respiratory symptoms and respiratory diseases amongst HIVpositive subjects: A cross-sectional study. AIDS Res Ther. 2010;7:6. https://doi. positive subjects: A cross-sectio
org/10.1186/1742-6405-7-6

5. Smith RL, De Boer R, Brul S, Budovskaya YV, Van der Spek H. Premature and accelerated aging: HIV or HAART? Front Genet [serial online]. 2013 [cited 2021 Apr 12];3. Available from: https://www.frontiersin.org/articles/10.3389/fgene.2012.00328/full

6. Feldman C. Pneumonia associated with HIV infection. Curr Opin Infect Dis 2005;18(2):165-170. https://doi.org/10.1097/01.qco.0000160907.79437.5a

7. Cribbs SK, Crothers K, Morris A. Pathogenesis of HIV-related lung disease: Immunity, infection, and inflammation. Physiol Rev. 2020;100(2):603-632. https://doi.org/10.1152/physrev.00039.2018 
8. Gingo MR, George MP, Kessinger CJ, et al. Pulmonary function abnormalities in HIV-infected patients during the current antiretroviral therapy era. Am J Respir Crit Care Med. 2010:182(6):790-796. https://doi.org/10.1164/rccm.200912 $18580 \mathrm{C}$

9. Varkila MRJ, Vos AG, Barth RE, et al. The association between HIV infection and pulmonary function in a rural African population. Lai PS, editor. PLoS One. 2019;14(1):e0210573. https://doi.org/10.1371/journal.pone.0210573

10. Tobacco - WHO.int [homepage on the Internet]. [cited 2020 Feb 01]. Available from: https://www.who.int/news-room/fact-sheets/detail/tobacco

11. Van Zyl Smit RN, Pai M, Yew WW, et al. Global lung health: The colliding epidemics of tuberculosis, tobacco smoking, HIV and COPD. Eur Respir J. 2010;35(1):27-33. https://doi.org/10.1183/09031936.00072909

12. Rahmanian S, Wewers ME, Koletar S, Reynolds N, Ferketich A, Diaz P. Cigarette smoking in the HIV-infected population. Proc Am Thorac Soc. 2011;8(3):313-319. https://doi.org/10.1513/pats.201009-058WR

13. Vos AG, Barth RE, Klipstein-Grobusch K, et al. Cardiovascular disease burden in rural Africa: Does HIV and antiretroviral treatment play a role?: Baseline analysis of the Ndlovu Cohort Study. J Am Heart Assoc. 2020;9(7):e013466. https://doi. org/10.1161/JAHA.119.013466

14. Sreeramareddy $C T$, Pradhan PM, Sin S. Prevalence, distribution, and social determinants of tobacco use in 30 sub-Saharan African countries. BMC Med. determinants of tobacco use in 30 sub-Saharan African
2014;12:243. https://doi.org/10.1186/s12916-014-0243-x

15. Roozen G, Vos AG, Tempelman HA, et al. Cardiovascular disease risk and its determinants in people living with HIV across different settings in South Africa. HIV Med. 2020;21(6):386-396. https://doi.org/10.1111/hiv.12831

16. Mutemwa M, Peer N, De Villiers A, Faber M, Kengne A-P. Tobacco smoking and associated factors in human immunodeficiency virus-infected adults attendin human immunodeficiency virus clinics in the Western Cape province South Africa. S Afr J HIV Med. 2020;21(1):1072. https://doi.org/10.4102/sajhivmed. v21i1.1072

17. Iliyasu Z, Gajida AU, Abubakar IS, Shittu O, Babashani M, Aliyu MH. Patterns and predictors of cigarette smoking among HIV-infected patients in northern Nigeria. Int J STD AIDS. 2012;23(12):849-852. https://doi.org/10.1258/ ijsa.2012.012001

18. Mdege ND, Shah S, Ayo-Yusuf OA, Hakim J, Siddiqi K. Tobacco use among people living with HIV: Analysis of data from Demographic and Health Surveys from 28 low-income and middle-income countries. Lancet Glob Health. 2017;5(6):e578e592. https://doi.org/10.1016/S2214-109X(17)30170-5

19. Bronner Murrison L, Martinson N, Moloney RM, et al. Tobacco smoking and tuberculosis among men living with HIV in Johannesburg, South Africa: A casecontrol study. PLoS One. 2016;11(11):e0167133. https://doi.org/10.1371/journal. pone.0167133

20. Waweru P, Anderson R, Steel H, Venter WDF, Murdoch D, Feldman C. The prevalence of smoking and the knowledge of smoking hazards and smoking cessation strategies among HIV- positive patients in Johannesburg, South Africa. S Afr Med J Suid-Afr Tydskr Vir Geneeskd. 2013;103(11):858-860. https://doi. org/10.7196/SAMJ.7388

21. Murphy JD, Liu B, Parascandola M. Smoking and HIV in sub-Saharan Africa: A 25-country analysis of the demographic health surveys. Nicotine Tob Res Off J Soc Res Nicotine Tob. 2019;21(8):1093-1102. https://doi.org/10.1093/ntr/nty176

22. George MP, Kannass M, Huang L, Sciurba FC, Morris A. Respiratory symptoms and airway obstruction in HIV-infected subjects in the HAART era. PLoS One. 2009;4(7):e6328. https://doi.org/10.1371/journal.pone.0006328

23. Drummond MB, Huang L, Diaz PT, et al. Factors associated with abnormal spirometry among HIV-infected individuals. AIDS Lond Engl. 2015;29(13):1691700. https://doi.org/10.1097/QAD.0000000000000750

24. North CM, Allen JG, Okello S, et al. HIV infection, pulmonary tuberculosis, and COPD in rural Uganda: A cross-sectional study. Lung. 2018;196(1):49-57. https:// doi.org/10.1007/s00408-017-0080-8

25. Verboeket SO, Boyd A, Wit FW, et al. Changes in lung function among treated HIVpositive and HIV-negative individuals: Analysis of the prospective AGE IV cohort study. Lancet Healthy Longev. 2021;2(4):e202-e211. https://doi.org/10.1016/ S2666-7568(21)00033-7

26. Hayes R, Sabapathy K, Fidler S. Universal testing and treatment as an HIV prevention strategy: Research questions and methods. Curr HIV Res. 2011;9(6):429-445. https://doi.org/10.2174/157016211798038515

27. South Africa National Department of Health. Implementation of the universal test and treat strategy for HIV positive patients and differentiated care for stable patients - Sahivsoc.org [homepage on the Internet]. 2016 [cited 2020 Feb 11] Available from: https://sahivsoc.org/Files/22\%208\%2016\%20Circular\%20 UTT $\% 20 \% 20 \% 20$ Decongestion $\% 20$ CCMT\%20Directorate.pdf

28. Vos AG. Study protocol: The influence of human immunodeficiency virus infection and antiretroviral treatment on cardiovascular profile and pulmonary condition in HIV-infected individuals in an urban setting in sub-Saharan Africa. The Netherlands; 2017
29. Vos AG, Hoeve K, Barth RE, et al. Cardiovascular disease risk in an urban African population: A cross-sectional analysis on the role of HIV and antiretroviral treatment. Retrovirology. 2019;16(1):37. https://doi.org/10.1186/s12977-019-0497-7

30. Jones PW, Quirk FH, Baveystock CM. The St George's Respiratory Questionnaire. Respir Med. 1991;85(Suppl B):25-31; discussion 33-37. https://doi.org/10.1016/ S0954-6111(06)80166-6

31. Graham BL, Steenbruggen I, Miller MR, et al. Standardization of spirometry 2019 update. An official American Thoracic Society and European Respiratory Society technical statement. Am J Respir Crit Care Med. 2019;200(8):e70-e88. https:// doi.org/10.1164/rccm.201908-1590ST

32. Brusasco V, Crapo R, Viegi G. [Coming together: The ATS/ERS consensus on clinical pulmonary function testing]. Rev Mal Respir. 2007;24(3 Pt 2):2S11-2S14.

33. Cotes JE. Medical research council questionnaire on respiratory symptoms (1986). Lancet. 1987;330(8566):1028. https://doi.org/10.1016/S0140-6736(87)92593-1

34. Standardized questionaries on respiratory symptoms. Br MedJ.1960;2(5213):1665. https://doi.org/10.1136/bmj.2.5213.1665

35. Ferris BG. Epidemiology standardization project (American Thoracic Society). Am Rev Respir Dis. 1978;118(6 Pt 2):1-120.

36. WHO. World Health Survey 2002: Individual questionnaire. Geneva: World Health Organization; 2002.

37. Mengersen $\mathrm{K}$, Morawska $\mathrm{L}$, Wang $\mathrm{H}$, et al. Association between indoor air pollution measurements and respiratory health in women and children in Lao PDR. Indoor Air. 2011;21(1):25-35. https://doi.org/10.1111/j.1600-0668.2010.00679.x

38. Isara AR, Aigbokhaode AQ. Household cooking fuel use among residents of a suburban community in Nigeria: Implications for indoor air pollution. Eurasian J Med. 2014;46(3):203-208. https://doi.org/10.5152/eajm.2014.0051

39. Harris PA, Taylor R, Thielke R, Payne J, Gonzalez N, Conde JG. Research electronic data capture (REDCap) - A metadata-driven methodology and workflow process for providing translational research informatics support. I Biomed Inform 2009;42(2):377-381. https://doi.org/10.1016/j.jbi.2008.08.010

40. Harris PA, Taylor R, Minor BL, et al. The REDCap consortium: Building an international community of software platform partners. J Biomed Inform. 2019;95:103208. https://doi.org/10.1016/j.jbi.2019.103208

41. Mengersen $\mathrm{K}$, Morawska L, Wang $\mathrm{H}$, et al. The effect of housing characteristics and occupant activities on the respiratory health of women and children in Lao PDR. Sci Total Environ. 2011;409(8):1378-1384. https://doi.org/10.1016/j.scitotenv.2011.01.016

42. James $G$, Witten $D$, Hastie $T$, Tibshirani R. An introduction to statistical learning. 7th ed. New York, NY: Springer; 2013.

43. Buuren S. Flexible imputation of missing data. Boca Raton, FL: CRC Press; 2018.

44. Von Hippel PT. How many imputations do you need? A two-stage calculation using a quadratic rule. Sociol Methods Res. 2020;49(3):699-718. https://doi. org/10.1177/0049124117747303

45. R: A Language and Environment for Statistical Computing. Vienna, Austria: R Foundation for Statistical Computing; 2020.

46. SPSS. Armonk, NY: IBM Corp; 2019

47. Rossouw TM, Anderson R, Feldman C. Impact of HIV infection and smoking on lung immunity and related disorders. Eur Respir J. 2015;46(6):1781-1795. https:// doi.org/10.1183/13993003.00353-2015

48. Peer N, Bradshaw D, Laubscher R, Steyn K. Trends in adult tobacco use from two South African Demographic and Health Surveys conducted in 1998 and 2003. S Afr Med J Suid-Afr Tydskr Vir Geneeskd. 2009;99(10):744-749.

49. Elf JL, Variava E, Chon S, et al. Prevalence and correlates of smoking among people living with HIV in South Africa. Nicotine Tob Res Off J Soc Res Nicotine Tob. 2018;20(9):1124-1131. https://doi.org/10.1093/ntr/ntx145

50. Vellios N, Van Walbeek C. Determinants of regular smoking onset in South Africa using duration analysis. BMJ Open. 2016;6(7):e011076. https://doi.org/10.1136/ bmjopen-2016-011076

51. Boachie MK, Ross H. Determinants of smoking intensity in South Africa: Evidence from township communities. Prev Med Rep. 2020;19:101099. https://doi. org/10.1016/j.pmedr.2020.101099

52. Reddy P, Zuma K, Shisana O, Jonas K, Sewpaul R. Prevalence of tobacco use among adults in South Africa: Results from the first South African National Health and Nutrition Examination Survey. S Afr Med J. 2015;105(8):648-655. https://doi. org/10.7196/SAMJnew.7932

53. Kunisaki KM, Niewoehner DE, Collins G, et al. Pulmonary effects of immediate versus deferred antiretroviral therapy in HIV-positive individuals: A nested substudy within the multicentre, international, randomised, controlled Strategic Timing of Antiretroviral Treatment (START) trial. Lancet Respir Med. 2016;4(12):980-989. https://doi.org/10.1016/S2213-2600(16)30319-8

54. Dillon DG, Gurdasani D, Riha J, et al. Association of HIV and ART with cardiometabolic traits in sub-Saharan Africa: A systematic review and metaanalysis. Int J Epidemiol. 2013;42(6):1754-1771. 


\section{Appendix 1}

\section{Elaboration on the Method section Measurements}

Study group I: For spirometry test, the KoKo® Sx 1000 handheld machine was used. Two outcomes were obtained from the spirometry test: the forced expiratory volume in 1 second (FEV1) in litres (L) and the forced vital capacity (FVC) in litres. ${ }^{31}$ Each participant was asked to perform a spirometry test twice: once before and once after administering four doses of $100 \mu \mathrm{g}$ salbutamol for bronchodilation. Each spirometry was repeated until three acceptable and reproducible attempts were obtained per participant, with a maximum of eight attempts per test. Acceptability and reproducibly were based on guidelines of the American Thoracic Society and European Respiratory Society. ${ }^{31,32}$ Participants with an abnormal spirometry test were referred to a pulmonologist for review. Definitions of an abnormal test were set up prior to start of the study (Table 1-A2).

A questionnaire was used to retrieve information on sociodemographics, history of lung and other diseases, and physical activity. The respiratory questionnaire was based on the St George's Respiratory Questionnaire (SGRQ), ${ }^{30}$ which was aimed at retrieving information on respiratory complaints, smoking, and pulmonary exposure during work and at home.

Smoking was limited to tobacco products (cigarettes, cigars and pipes) and was classified into never versus ever (past and current) smokers. Race was defined as black or nonblack. HIV status was based on test results from UTT or ART prescription. Time since HIV diagnosis was measured in months. Education was divided into two groups: less than secondary school completed and secondary school completed or higher. Work status was split into four groups: employed, unemployed, retired and student. Relationship status was dichotomised into stable relationship yes or no, with stable relationship being defined as married or in a self-defined stable relationship. Alcohol use was defined as ever or never. Time spent close to an open fire was divided into daily versus less than daily and was defined as fire time. The presence of a smoker in the household during childhood was defined as smoking household. Smoking inside the house during childhood was defined as smoking household indoor. Fireplace childhood was defined as the presence of an indoor fireplace in childhood home. Parental lung disease was defined as either one of the participant's parents being diagnosed with a chronic pulmonary disease. Occupational hazard was dichotomised into ever versus never, and was defined as exposure to gases, chemical fumes or chemicals during work, working in a dusty job, or working in the farming or mining industry for more than a year. Breathing problems was classified into presence or absence of breathing or chest troubles or symptoms in the past three months.

Study group II: The measurements taken in Study II were identical to those in Study I. Comparable questionnaires were used to assess demographics, characteristics and respiratory profile of participants of both the study groups. The respiratory questionnaire was based on the SGRQ, ${ }^{30}$ the British Medical Research Council Respiratory Questionnaire, $^{33,34}$ the ATS-DLD-78-A, ${ }^{35}$ the World Health Survey $^{36}$ and questionnaires used in other publications. ${ }^{37,38}$ Physical examination was also performed. For spirometry, a Spida 5 handheld machine was used with similar procedures and outcome assessment to the KoKo® Sx 1000 handheld machine.

TABLE 1-A1: Results of multivariable analysis for post-bronchodilator (BD) forced expiratory volume in 1 second and the forced expiratory volume in 1 second/ forced vital capacity ratio, of imputed data sets.

\begin{tabular}{|c|c|c|c|c|}
\hline \multirow[t]{2}{*}{ Variable } & \multicolumn{2}{|c|}{$\begin{array}{l}\text { Model 1: without } \\
\text { history of TB }\end{array}$} & \multicolumn{2}{|c|}{$\begin{array}{l}\text { Model 2: with } \\
\text { history of TB }\end{array}$} \\
\hline & $\begin{array}{c}\text { Post-BD } \\
\text { FEV1 } \\
(\beta \text {-coefficient } \dagger)\end{array}$ & $\begin{array}{c}\text { Post-BD } \\
\text { FEV1/FVC } \\
\text { ( } \beta \text {-coefficient } \dagger)\end{array}$ & $\begin{array}{c}\text { Post-BD } \\
\text { FEV1 } \\
(\beta \text {-coefficient } \dagger)\end{array}$ & $\begin{array}{c}\text { Post-BD } \\
\text { FEV1/FVC } \\
(\beta \text {-coefficient } \dagger)\end{array}$ \\
\hline Smoking ever & $<0.001$ & 0.004 & 0.001 & 0.004 \\
\hline Age (years) & $-0.022 * *$ & $-0.002 * *$ & $-0.022 * *$ & $-0.002 * *$ \\
\hline Sex (male) & $0.836 * *$ & $-0.020 * *$ & $0.847 * *$ & $-0.019 *$ \\
\hline BMI $\left(\mathrm{kg} / \mathrm{m}^{2}\right)$ & $-0.008^{*}$ & $-0.001^{*}$ & $-0.008^{*}$ & $-0.001 *$ \\
\hline $\begin{array}{l}\text { Time since HIV } \\
\text { diagnosis } \\
\text { (months) }\end{array}$ & $<0.001$ & $<0.001$ & $<0.001$ & $<0.001$ \\
\hline $\begin{array}{l}\text { ART duration } \\
\text { (months) }\end{array}$ & $<-0.001$ & $<-0.001$ & $<-0.001$ & $<-0.001$ \\
\hline $\begin{array}{l}\text { Occupational } \\
\text { hazard } \ddagger\end{array}$ & 0.032 & $<0.001$ & 0.023 & $<0.001$ \\
\hline $\begin{array}{l}\text { History of } \\
\text { pneumonia }\end{array}$ & $-0.132^{*}$ & $-0.023 *$ & -0.090 & -0.019 \\
\hline $\begin{array}{l}\text { Smoke household } \\
\text { indoort: }\end{array}$ & -0.043 & 0.005 & -0.035 & 0.006 \\
\hline $\begin{array}{l}\text { Fireplace } \\
\text { childhood } \$\end{array}$ & $-0.105^{*}$ & 0.001 & $-0.108 *$ & $<0.001$ \\
\hline History of TB & - & - & $-0.200 * *$ & $-0.018 * *$ \\
\hline
\end{tabular}

$\mathrm{BD}$, bronchodilator; BMI, body mass index; FEV1, forced expiratory volume in 1 second; FVC forced vital capacity; TB, tuberculosis.

$*, p<0.05 ; * *, p<0.01$.

$\dagger, \beta$-coefficients are the result of multivariable analysis and are unstandardised; $\ddagger$, Definitions of variables can be found in Methods: Measurements.

TABLE 2-A1: Spirometry definitions.

\begin{tabular}{ll}
\hline Diagnosis & Criteria \\
\hline Asthma & FEV1/FVC $<0.70$, and pre- and post-bronchodilation \\
& FEV1 difference of $12 \%$ and $200 \mathrm{~mL}$ or more \\
COPD & $\begin{array}{l}\text { FEV1/FVC }<0.70, \text { and no pre- and post-bronchodilation } \\
\text { FEV1 difference of } 12 \% \text { and } 200 \mathrm{~mL} \text { or more }\end{array}$ \\
Obstructive lung disease & FEV1/FVC $<0.70$, and FEV1 $<80 \%$ of predicted value \\
Healthy lung function & $\begin{array}{l}\text { FEV1/FVC }>0.70, \text { and FEV1 or FEV1/FVC }>80 \% \text { of } \\
\text { predicted value }\end{array}$ \\
\hline
\end{tabular}

FEV1, forced expiratory volume in 1 second; FVC, forced vital capacity; COPD, chronic obstructive pulmonary disease. 